\title{
The Role of European Courts in the Development of a Hierarchy of Norms within International Law: Evidence of Constitutionalisation?
}

\author{
Erika de Wet*
}

\begin{abstract}
Constitutionalism - Kadi ruling of EU Court of First Instance - Erosion of 'total' constitutional order by reallocation of public power - Constitutional vision challenge of networks approach - Emerging human rights hierarchy - Rudimentary international value system - Ius cogens and erga omnes - Barcelona Traction - Core human rights elements - Enforcement through regional and domestic courts Review of Security Council resolutions
\end{abstract}

\section{Defining Constitutionalism AND ITS RELEVANCE}

In the Kadi decision of 2005, the European Court of First Instance affirmed the absence of a right to a fair trial of individuals residing in European Union member states and whose assets were frozen, due to their blacklisting by the United Nations Security Council for being suspected of involvement with international terrorism. ${ }^{1}$ This decision was an upshot of Security Council Resolutions 1267 (1999) and 1333 (2000), which were adopted in the aftermath of the attacks on the United States' embassies in Kenya and Tanzania and the suspected involvement of Osama Bin Laden therein. ${ }^{2}$ These resolutions, geared towards pressur-

* Prof. Dr. Iur., LL.M. (Harvard); Prof. of International Constitutional Law, University of Amsterdam [Universiteit van Amsterdam], the Netherlands; Extraordinary Prof., North-West University (Potchefstroom campus) and University of Pretoria (South Africa). This contribution forms part of a so-called VICI Project of the Netherlands Organisation for Scientific Research [Nederlandse Organisatie voor Wetenschappelijk Onderwijs, NWO] entitled: The Emerging International Constitutional Order: the Implications of Hierarchy in International Law for the Coherence and Legitimacy of International Decision-making.

${ }^{1}$ CFI 21 Sept. 2005, Case No. T-315/01, Yassin Abdullah Kadiv. Council of the European Union and Commission of the European Communities (Kadi case); See also the identical case of CFI 21 Sept. 2005, Case No. T-306/01, Ahmed Ali Yusuf and Al Barakaat International Foundation v. Council of the European Union and Commission of the European Communities (Yusuf case).

${ }^{2}$ SC Res. 1267 of 15 Oct. 1999, reprinted in 39 ILM 2000 p. 235; SC Res. 1333 of 19 Dec. 2000, reprinted in 40 ILM 2001 p. 509. 
ing the (then) de facto Taliban regime in Afghanistan into extraditing Osama Bin Laden to the United States, authorised a Security Council Sanctions Committee (the Al-Qaeda Committee), to identify and blacklist individuals and entities who are associated with the Taliban, Osama Bin Laden and Al-Qaeda (the Al-Qaeda sanctions regime). ${ }^{3}$ As a result their assets are frozen by their state of residence until such time as the Sanctions Committee itself decides to remove them from the list.

Since the attacks on the United States of 11 September 2001, the Al-Qaeda Committee has been very active in expanding the list of targeted persons and entities. Although the Security Council lifted the sanctions against Afghanistan after the fall of the Taliban regime in Resolution 1390 (2002), ${ }^{4}$ this open-ended resolution has maintained the sanctions against the Taliban, Osama Bin Laden and Al-Qaeda. Neither Resolution $1267(1999)^{5}$ nor any of its follow-up resolutions explicitly provides for access to an independent judicial body that could provide relief against the listing procedure. ${ }^{6}$ The European Union implemented Resolution 1267 (1999) ${ }^{7}$ and subsequent resolutions through Common Positions and Regulations in order to ensure uniform application in all member states. ${ }^{8}$ The respective Regulations had direct effect, and as they did not explicitly provide for an independent review mechanism, the issue of the right to a fair trial was bound to arise before the European Court of First Instance (and subsequently on appeal before the European Court of Justice).

Although this CFI decision was subsequently overturned on appeal, it remains a memorable example of the increasing tension between fundamental human rights norms and other international obligations such as international peace and security in the post-9/11 era. In addition, it is a clear illustration of the direct relevance for individuals of the intensification in the shift of public decision-making away from the nation state towards international actors such as international organisations, as it can no longer be said that these decisions are only of an inter-state nature.

Moreover, the European Court of First Instance's Kadi decision ${ }^{9}$ illustrates the increasing difficulty of any of the respective international legal subjects (the United

${ }^{3}$ SC Res. 1267 (1999), supra n. 2; SC Res. 1333 (2000), supra n. 2 at para. 8(c); and SC Res. 1390 of 16 Jan. 2002, reprinted in 41 ILM 2002 p. 511 at paras. 2(a) and 5(a).

${ }^{4}$ SC Res. 1390 (2002), supra n. 3.

${ }^{5}$ SC Res. 1267 (1999), supra n. 2.

${ }^{6}$ See M. Bulterman, 'Fundamental Rights and the United Nations Financial Sanctions Regime: The Kadi and Yusuf Judgments of the Court of First Instance of the European Communities', 19 Leiden Journal of International Law (2006) p. 753 at p. 755.

${ }^{7}$ SC Res. 1267 (1999), supra n. 2.

8 See, inter alia, Council Common Position 2002/402/CSFP, OJ [2002] L 139/4, 29.5.2002 and Council Regulation 881/2002, OJ [2002] L 139/9, 29.5.2002; See extensively Bulterman, supra n. 6, at p. 758.

${ }^{9}$ Kadi decision, supra n. 1. 
Nations, the European Union, member states) to independently reconcile different sets of international obligations. This perception was enhanced by subsequent developments on appeal, during which the European Court of Justice came to the opposite conclusion and stressed the fundamental importance of the right to a fair trial within the legal order of the European Union. ${ }^{10}$ Since the reasoning of the European Court of Justice was based exclusively on EU law and did not address the validity of the European Court of First Instance's arguments from the perspective of public international law, it remained unclear if and to what extent its acknowledgment of the importance of human rights protection resulted in a violation of the member states' obligations pertaining to international security.

These potentially clashing international obligations also represent obligations that traditionally constituted core elements of the exercise of public power within the nation state, namely the protection of public safety versus the protection of individual liberties. The Kadi decision ${ }^{11}$ poignantly illustrates the eroding impact of the continuous (re)allocation of public power between different international legal subjects on the concept of a 'total' constitutional order, where the fundamental substantive and structural norms that constitute the supreme legal framework for the exercise of public power are concentrated in the nation state. ${ }^{12}$

The decision further underpins the submission that such a supreme legal framework is only possible in a system where national, regional (e.g., the European Union) and functional (e.g., the World Trade Organisation and the United Nations) legal orders complement each other in order to form an international constitutional order. ${ }^{13}$ This order refers to the fundamental structural and substantive norms unwritten as well as codified - of the international legal order as a whole, which contain the outer limitations for the exercise of public power. The fundamental substantive elements of the international constitutional order primarily include the value system of the international legal order, meaning norms of positive law with a strong ethical underpinning (notably human rights norms) that have ac-

${ }^{10}$ ECJ, Yassin Abdullah Kadi \& Al Barkaat International Foundation v. Council \& Commission, 3 Sept. 2008, Joined Cases C-402/05 P \& C-415/05 P, at para. 316, 326; See also ECJ, Opinion of A.G. Poiares Maduro, 16 Jan. 2008, Case C-402/05 P, Yassin Abdullah Kadi v. Council of the European Union and Commission of the European Communities. Both documents are available at $<\mathrm{http} / / /$ curia.europa.eu>, visited 18 Feb. 2009; Cf. S. Besson, 'How International is the European Legal Order? Retracing Tuori's Steps in the Exploration of European Legal Pluralism', 5 No Foundations (2008) p. 50 at p. 59 et seq.

${ }^{11}$ Kadi decision, supra n. 1.

${ }^{12}$ C. Walter, 'Constitutionalizing (Inter)national Governance - Possibilities for and Limits to the Development of an International Constitutional Law', 44 German Yearbook of International Law (2001) p. 170 at p. 192.

${ }^{13}$ E. de Wet, 'The International Constitutional Order', 55 International \& Comparative Law Quarterly (2006) p. 51 at 51 et seq. 
quired a special hierarchical standing vis-à-vis other international norms through state practice. ${ }^{14}$ The fundamental structural elements include the subjects of the international legal order that collectively form the international community and which provide mechanisms for the enforcement of the international value system. The international community is composed predominantly of states, which still remain central to international law-making and enforcement. Regional and functional organisations with legal personality, e.g., the European Union, the World Trade Organisation and the United Nations, and individuals (albeit to a limited extent) also participate in the membership of the international community. ${ }^{15}$

In accordance with this line of argument, the term 'constitution' is not exclusively reserved for the supreme legal framework of (sovereign) states, as the fundamental legal framework of any community can be so defined. ${ }^{16}$ In the current context the notion of 'constitution' is used to describe a system in which the different national, regional and functional regimes form the building blocks of the international community ('international polity') that is underpinned by a core value system common to all communities and embedded in a variety of decentralised legal structures for its enforcement. Constitutionalisation refers to the interaction of the different regimes through which the fundamental legal framework of the international legal order containing the outer limits for the exercise of public power emerges.

This vision of an emerging international constitutional order challenges the networks approach. According to the latter, the international legal order is characterised by the existence of various functional regimes, which would determine the outcome of any inter-regime conflicts. ${ }^{17}$ The logical consequence of this line of argument would be that decisions such as those of the European Court of First Instance in the Kadi case ${ }^{18}$ in which human rights protection of individuals can effectively be abolished by functional regimes pertaining to, inter alia, peace and security, are likely to increase in an era where decisions of international organisations (functional regimes) are increasingly directed at individuals rather than states. This, in turn, is bound to result in a creeping (re-) establishment

${ }^{14}$ See also P.M. Dupuy 'Some Reflections on Contemporary International Law and the Appeal to Universal Values: A Response to Martti Koskenniemi', 16 European Journal of International Law (2005) p. 131 at p. 133.

${ }^{15}$ E. de Wet, 'The Emergence of International and Regional Value Systems as a Manifestation of the Emerging International Constitutional Order', 19 Leiden Journal of International Law (2006) p. 611 at p. 611-612.

${ }^{16}$ B. Fassbender, 'The United Nations Charter as Constitution of the International Community', 36 Columbia Journal of Transnational Law (1998) p. 529 at p. 532-538; See also idem at p. 555-561.

${ }^{17}$ A. Fischer-Lescano and G. Teubner, 'Regime-Collisions: The Vain Search for Legal Unity in the Fragmentation of Global Law', 25 Michigan Journal of International Law (2004) p. 999 at p. 999.

${ }^{18}$ Kadi decision, supra n. 1 and n. 10. 
of absolute public power over private individuals. The approach proposed by the author differs from the networks perspective by arguing that the different functional regimes within the international legal order function as complementary elements of a larger whole. This would be the embryonic international constitutional order within which an international value system characterised by hierarchical elements is emerging, which can provide some guidance for solving potential conflicts between regimes.

The subsequent analysis attempts to illustrate in particular that the existence of a hierarchically superior value system across different regimes (whether domestic, regional, functional) can reduce the potential for inter-regime normative conflict. In addition, the analysis draws attention to the potential role of domestic and regional courts in developing this value system. In an era in which international obligations - notably those stemming from international organisations frequently have direct consequences for individuals, domestic and regional courts will increasingly be confronted with disputes in which these obligations seem to clash with, inter alia, human rights obligations. ${ }^{19}$ This will typically occur where domestic or regional courts are confronted with challenges to (the legality of) domestic or regional measures that implement an international obligation, such as a Security Council resolution. ${ }^{20}$ In the process, the court may be confronted with reviewing the scope, meaning and even the legality of the international obligation itself. Such was the situation with the Kadi dispute, ${ }^{21}$ which was rooted in Security Council Resolutions 1267 of 15 October 1999 and 1333 of 19 December 2000, ${ }^{22}$ and the measures subsequently adopted within the European Union in order to implement them in a uniform manner throughout all member states.

The analysis first elaborates on the contours of the embryonic international value system, including its relationship with the United Nations and its organs. Given the special nature of Security Council resolutions and the resulting obligations for member states under Article 103 of the United Nations Charter (the Charter), ${ }^{23}$ the question of whether an emerging international human rights hierarchy would prevail or perish when conflicting with binding Security Council resolutions, can serve as an indication of the current stage of development of the international value system and its potential viability. In this context, the Kadi decision of the European Court of First Instance ${ }^{24}$ serves as a frame of reference for exploring the relationship between Article 103 of the Charter and peremptory

${ }^{19}$ E. de Wet and A. Nollkaemper, 'Review of the Security Council Decisions by National Courts', 45 German Yearbook of International Law (2003) p. 166 at p. 184 et seq.

${ }^{20}$ De Wet and Nollkaemper, supra n. 19 at p. 195.

${ }^{21}$ Kadi decision, supra n. 1 and n. 10.

${ }^{22}$ SC Res. 1267 (1999) supra n. 2; SC Res. 1333 (2000) supra n. 2.

${ }^{23}$ Charter of the United Nations 1945, 59 Stat. 1031.

${ }^{24}$ Kadi case, supra n. 1. 
norms of international law (jus cogens), as well as the relationship between Article 103 and other international human rights standards. As mentioned, this aspect of the reasoning of the Court of First Instance remained untouched by the European Court of Justice. This fact, combined with the fact that the arguments of the Court of First Instance pertaining to jus cogens have since been taken over by other domestic courts in Europe, means that the decision of the Court of First Instance still remains very relevant from the perspective of public international law - despite the fact that the consequences of the decision were overturned. ${ }^{25}$ Thereafter, the focus shifts to exploring the role of regional and domestic courts in enforcing the international value system.

\section{THE CONTOURS OF THE INTERNATIONAL VALUE SYSTEM AND ITS IMPLICATIONS FOR THE UNITED NATIONS}

The rudimentary international value system is of a layered nature, that includes the (sometimes overlapping) layers of universal jus cogens norms and erga omnes obligations. The fact that most of the international norms qualifying as jus cogens and/or erga omnes norms are human rights norms supports the view that human rights have developed into the core of the international value system. ${ }^{26}$ The normatively superior character of jus cogens norms was introduced in positive international law through Article 53 of the Vienna Convention on the Law of Treaties of 1969 (the Vienna Convention), ${ }^{27}$ with the primary aim of placing the deviation from peremptory norms beyond the treaty-making competence of states. ${ }^{28}$

${ }^{25}$ The reasoning of this decision was subsequently taken over by the Swiss Federal Supreme Court in a case with very similar facts, namely BGE 14 Nov. 2007, No. 1A.45/2007, Youssef Mustapha Nada v. Staatssekretariat für Wirtschaft (Nada case). The Nada decision was rendered by the Federal Supreme Court, available at <http://www.admin.ch/ch/d/sr/sr.html>, visited 18 Feb. 2009; See also [2005] EWHC 1809 (Admin), 12 Aug. 2005, R. (on the application of Hilal Abdul-Razzaq Al-jedda) v. Secretary of State for Defence, Queen's Bench Division (Al-Jedda case) at para. 55 et seq. On 29 March 2006, the English Court of Appeal relied on the reasoning of the European Court of First Instance Kadi case, supra n. 1, to justify the interment without trial of a British citizen in Iraq. The Court accepted the state's argument that the SC Res. 1456 of 20 Jan. 2003, reprinted in 42 International Legal Material (ILM) 2003 p. 510, allowed the British military to suspend, in effect, individual rights such as the right to contest the lawfulness of one's detention under Art. 5(1) of the European Convention on Human Rights 1950, 213 United Nations Treaty Series (UNTS) p. 221 (ECHR). This decision was upheld on appeal, although the House of Lords did not address the arguments of the Kadi case, supra n. 1, and followed a different reasoning, see [2007] UKHL 58, 12 Dec. 2007, $R$ (on the application of Al-jedda) v. Secretary of State for Defence.

${ }^{26}$ De Wet 2006 (International Comparative Law Quarterly), supra n. 13. For controversies pertaining to the international value system, including its (lack of) legitimacy, see ibid. at p. 71 et seq.

${ }^{27}$ Vienna Convention on the Law of Treaties 1969, 1155 UNTS p. 331 (the Vienna Convention).

${ }^{28}$ See in particular A. Orakhelashvili, Peremptory Norms in International Law (Oxford, Oxford University Press 2006); See also S. Kadelbach and T. Kleinlein, 'International Law - a Constitution 
The concept of erga omnes obligations gained recognition through the jurisprudence of the International Court of Justice, when it distinguished between the obligations of a state towards the international community as a whole, and those borne towards other (individual) states. In the Barcelona Traction case, ${ }^{29}$ the International Court of Justice determined that the former obligations are the concern of all states. In view of the importance of the rights involved, all states can be held to have a legal interest in their protection: they are obligations erga omnes. The notion of erga omnes obligations also finds recognition in the Articles on State Responsibility of $2001,{ }^{30}$ where a distinction is drawn between breaches of bilateral obligations and obligations of a collective interest nature, which include obligations towards the international community as a whole. ${ }^{31}$

The Barcelona Traction decision ${ }^{32}$ of the International Court of Justice provides authority for the conclusion that jus cogens norms would have erga omnes effect. Without expressly referring to jus cogens the International Court of Justice implied as much by the types of (notably human rights) norms it mentioned as examples of erga omnes norms. ${ }^{33}$ These included the outlawing of the unilateral use of force, ${ }^{34}$ genocide and the prohibition of slavery and racial discrimination. Given the fact that these same prohibitions are widely regarded as being of a peremptory nature, one can conclude that a norm, from which no derogation is permitted due to its fundamental nature, will ordinarily be applicable to all members of the legal com-

for Mankind? An Attempt at a Re-appraisal with an Analysis of Constitutional Principles', 50 German Yearbook of International Law (2007), p. 303 at p. 313 et seq.; See also A. Bianchi, 'Human Rights and the Magic of Jus Cogens', 19 European Journal of International Law (2008), p. 491 at p. 491 et seq.

29 See ICJ, Barcelona Traction, Light and Power Company, Limited (Second Phase) (Barcelona Traction case), Judgment, ICJ Reports (1970) p. 3; ICJ, Legal Consequences of the Construction of a Wall in the Occupied Palestinian Territory, Advisory Opinion, ICJ Reports (2004) p. 174, available at <www.icjcij.org>, visited 18 Feb. 2009; See also 'Report of the International Law Commission', 58 ${ }^{\text {th }}$ Session of the International Law Commission, A/61/10 (2006) at p. 419, available at <http://www.un.org/ law/ilc/>, visited 18 Feb. 2009.

${ }^{30}$ International Law Commission, 'Draft Articles on Responsibility of States for Internationally Wrongful Acts, with Commentaries', Yearbook of the International Law Commission 2001, Vol. II, part 2. The text is available via <http://untreaty.un.org/ilc>, visited 18 Feb. 2009.

31 See the commentary to Art. 42 and Art. 48 in J.R. Crawford, The International Law Commission's Articles on State Responsibility: Introduction, Text and Commentaries (Cambridge, Cambridge University Press 2002); See also 'Report of the International Law Commission', supra n. 29, at p. 421; See generally C.J. Tams, Enforcing Obligations Erga Omnes in International Law (Cambridge, Cambridge University Press 2005).

32 Barcelona Traction case, supra n. 29.

${ }^{33}$ J.A. Frowein 'Collective Enforcement of International Obligations', 47 Zeitschrift für Ausländisches Öffentliches Recht und Völkerrecht (1987) p. 67 at p. 71; See also K. Zemanek, New Trends in the Enforcement of Erga Omnes Obligations', 4 Max Planck Yearbook of United Nations Law (2000) p. 1 at p. 6-7; See also 'Report of the International Law Commission', supra n. 29 at p. 421.

${ }^{34}$ The prohibition of the use of force is the only peremptory norm which is of an inter-state nature, rather than a human rights norm. 
munity ${ }^{35}$ One should be careful, however, not to assume that the opposite also applies, namely that all erga omnes norms would constitute peremptory norms of international law. ${ }^{36}$

For example, the human rights obligations contained in the International Covenant on Civil and Political Rights of 1966 (ICCPR) ${ }^{37}$ and the International Covenant on Economic, Social and Cultural Rights of 1966 (ICESCR) ${ }^{38}$ all have erga omnes effect to the extent that they have acquired customary international law status. ${ }^{39}$ Their collective interest nature gives the international community as a whole an interest in their performance and shows that they amount to more than mere 'bundles of bilateral obligations'. ${ }^{40}$ In and of itself, however, this fact does not elevate all erga omnes human rights obligations to peremptory norms. The peremptory character of the prohibition of genocide and torture resulted from their specific recognition as such by a large majority of states. ${ }^{41}$ Customary erga omnes norms without peremptory status would therefore constitute a second layer of the international value system, below that of peremptory norms.

Given the limited number of jus cogens norms and the uncertainties surrounding the customary status of the rights in the international human rights instruments, ${ }^{42}$ one has to admit that the scope of the international value system remains limited and uncertain. Even so, it is arguable that its scope is significantly more concrete in as far as it relates to the United Nations and its organs. Stated differ-

35 J.A. Frowein, 'Obligations Erga Omnes', in R. Bernhardt (ed.), Encyclopaedia of International Law Vol. III (Amsterdam, Elsevier 1997) at p. 757; See also 'Report of the International Law Commission', supra n. 29, at p. 421.

${ }^{36}$ See 'Report of the International Law Commission', supra n. 29, at p. 421; See also P.M. Dupuy 'L'unité de l'ordre juridique international: cours général de droit international public (2000)', 297 Recueil des cours de l'académie de droit international (2002) p. 9 at p. 385.

${ }^{37}$ International Covenant for Civil and Political Rights (16 Dec. 1966) (ICCPR), 999 UNTS p. 171

${ }^{38}$ International Covenant for Economic, Social and Cultural Rights (16 Dec. 1966) (ICESCR), 993 UNTS p. 3

${ }^{39}$ Although the extent to which any of these norms acquired customary status remains a contested point, all obligations under the ICCPR and ICESCR would have erga omnes partes effect. See Dupuy 2002, supra n. 36, at footnote 762, p. 382; See also 'United Nations Human Rights Committee, General Comment No. 31 [80] Nature of the General Legal Obligation Imposed on States Parties to the Covenant, CCPR/C/21/Rev.1/Add.13, 26 May 2004, para. 2 available via <http://www.unhcr. ch.tbs>, visited 18 Feb. 2009; See also I. Seiderman, Hierarchy in International Law (Antwerp, Intersentia 2001) at p. 145.

${ }^{40}$ See Crawford, supra n. 31, at p. 258.

${ }^{41} \mathrm{See}$ 'Report of the International Law Commission', supra n. 29, at p. 421; For an overview of the jurisprudence concerning the peremptory character of the prohibition of genocide and torture, respectively, see Dupuy 2002, supra n. 36, at p. 295-299.

42 See G. Thalinger, 'Sense and Sensibility of the Human Rights Obligations of the United Nations Security Council', 67 Zeitschrift für ausländisches öffentliches Recht und Völkerrecht (2007), p. 1015 at p. 1022 et seq. 
ently, the international value system would also contain a third layer, specifically relating to the United Nations as an organisation. Given the reach of this organisation's competence - especially when acting under Chapter VII of the Charter - this layer could have significant practical importance. This author has argued extensively that the United Nations organs, including the Security Council, would be bound by the core content of the human rights contained in all United Nations human rights treaties, despite the fact that the United Nations is not a party to any of them. ${ }^{43}$ This argument is distilled from public international law itself, namely from Article 24(2) of the Charter, read together with Articles 1(1), 1(3) and 2(2) of the Charter. Article 24(2) of the Charter determines that in discharging its duties, the Security Council shall act in accordance with the purposes and principles of the United Nations, which in the present context are contained, in particular, in Articles 1(1), 1(3) and 2(2) of the Charter. ${ }^{44}$

Article 1(1) of the Charter articulates the primary goal of the United Nations, namely the maintenance of international peace and security and the peaceful settlement of disputes in accordance with international law and procedural justice. ${ }^{45}$ Article 2(2) of the Charter requires that the United Nations (and its organs) respects the principle of good faith, whereas Article 1(3) of the Charter obliges the organisation to protect human rights. According to the author's line of argument, the principle of good faith as articulated in Article 2(2) of the Charter is closely related to the concept of equitable (promissory) estoppel, which had initially been developed in inter-state relations, but also applies to international organisations as a general principle of law. Where a country or an international organisation has created the legitimate expectation that it would act in a certain manner, it is under a legal obligation to fulfil that expectation. ${ }^{46}$ More concretely, in light of the interaction of the principle of good faith with Articles 1(1) and 1(3) of the Charter, the principle of good faith would estop the organs of the United Nations from behaviour that violates the rights and obligations flowing from these articles. As a result, the Security Council would be estopped from behaviour that violates the

43 See De Wet and Nollkaemper, supran. 19 at 171 et seq; See generally also E. de Wet, The Chapter VII Powers of the United Nations Security Council (Oxford, Hart 2004).

${ }^{44} \mathrm{See}$ E. de Wet, 'Holding the United Nations Security Council Accountable for Human Rights Violations through Domestic and Regional Courts: A Case of Beware What You Ask For?', in J. Farrall and K. Rubenstein (eds.), Sanctions Accountability and Governance in a Globalised World (2009, forthcoming).

${ }^{45}$ Art. 1(1) of the UN Charter, supra n. 23, reads: '[The Purposes of the United Nations are:] To maintain international peace and security, and to that end: to take effective collective measures for the prevention and removal of threats to peace, and for the suppression of acts of aggression, or other breaches of the peace, and to bring about by peaceful means, and in conformity with the principles of justice in international law, adjustment or settlement of international disputes or situations which might lead to a breach of the peace $[\ldots]$.'

${ }^{46}$ See ICJ, Nuclear Tests (Australia v. France), Judgment, ICJ Reports (1974) p. 253 at p. 267. 
core elements of the human rights norms underpinning Article 1(3) of the Charter. $^{47}$

One can draw these core human rights elements from the human rights instruments developed under the auspices of the United Nations itself. ${ }^{48}$ These documents represent an elaboration of the Charter's original human rights vision as found in Article 1(3) and Articles 55 and 56 of the Charter. The human rights contained in these documents thus constitute the human rights that, under Article 1(3) of the Charter, the United Nations must promote and respect. The United Nations is not a party to these instruments but was, however, created under their auspices, and has also created an elaborate system for monitoring their implementation by member states. This created the expectation that the (organs of the) organisation itself should respect the core content of the norms which that same organisation propagates. The obligation to act in good faith thus obliges the member states, when acting in the context of an organ of the United Nations, to fulfil legally relevant expectations that are raised by their conduct with regard to international human rights standards adopted in the framework of the organisation. It also implies that those (permanent) members of the Security Council that have not yet ratified any of the aforementioned Covenants are nonetheless bound to the core of the rights contained therein when acting on behalf of the organisation itself. ${ }^{49}$

This line of argument acknowledges that the adoption of coercive measures (such as targeted sanctions) in the interest of international peace and security can result in the limitation of rights and obligations under international law - including human rights obligations - as long as the core content of the rights in question is respected. It thus rejects the notion that the Security Council can deviate completely from international human rights standards when adopting binding measures under Chapter VII of the Charter. It also rejects the European Court of

${ }^{47}$ De Wet and Nollkaemper, supra n. 19, at p. 8

48 These include the Universal Declaration of Human Rights of 10 Dec. 1948; the International Covenant on Civil and Political Rights of 16 Dec. 1966 and the Protocols thereto; the International Covenant on Economic, Social and Cultural Rights of 16 Dec. 1966; the Convention on the Elimination of All Forms of Racial Discrimination of 21 Dec. 1965; the Convention on Elimination of All Forms of Discrimination Against Women of 17 Dec. 1979 and the Protocol thereto; the Convention Against Torture and Other Cruel, Inhumane or Degrading Treatment or Punishment of 17 Dec. 1984 and the Protocol thereto; the International Convention on the Rights of the Child of 20 Dec. 1989; the International Convention on the Protection of the Rights of All Migrant Workers and Members of Their Families of 18 Dec. 1990; and the Convention on the Rights of Persons with Disabilities of 13 Dec. 2006 and the Protocol thereto; The text of these and all other United Nations human rights documents cited in this article are available at <http://www. unhchr/ch>, visited 18 Feb. 2009; See also De Wet and Nollkaemper, supra n. 19.

49 See extensively E. De Wet, The Chapter VII Powers of the United Nations Security Council (Oxford, Hart 2004), in particular ch. 4. 
First Instance's conclusion in the Kadi case ${ }^{50}$ that the Security Council is only bound by the very small number of peremptory norms of international law (jus cogens).

The European Court of First Instance's analysis of the Charter framework reflects an insufficient appreciation of the obligation to respect the Charter purposes and principles as articulated in Article 24(1) of the Charter. The European Court of First Instance acknowledged that Article 24(2) of the Charter obliges the (organs of the) United Nations to respect the purposes and principles of the Charter which include respect for human rights and fundamental freedoms. ${ }^{51}$ However, at the same time the European Court of First Instance equated the human rights standards contained in the purposes and principles of the Charter to jus cogens obligations. By doing so, the Court severely limited their scope and impact. ${ }^{52}$ This is rather perplexing, since the purposes and principles are drafted in broad language. ${ }^{53}$ In addition, the concept of jus cogens was not generally recognised at the time the Charter was adopted. The concept that was applied by the Court of First Instance was only introduced into positive law through Article 53 of the Vienna Convention. ${ }^{54}$

It thus seems unconvincing to reduce the scope of the purposes and principles of the Charter to a narrow category of norms whose existence was only formally acknowledged at a much later point in time. One should also consider the fact that the concept of jus cogens was first and foremost introduced to invalidate inter-state treaties that violate peremptory norms of international law. The question therefore also arises whether jus cogens would apply at all to decisions of international organisations and their organs. ${ }^{55}$ Current legal doctrine tends to answers this ques-

${ }^{50}$ Kadi case, supra n. 1.

${ }^{51}$ Kadi decision, supra n. 1, at paras. 228-229; See also Nada decision, supra n. 25, at paras. 5.4 and 7 .

${ }^{52}$ For the very restricted list of jus cogens norms generally recognised as such, see 'Report of the International Law Commission', supra n. 29, at p. 421; For a different opinion, see Orakhelashvili, supra n. 28, who defines jus cogens much more broadly.

${ }^{53}$ For example, in ICJ, Case Concerning United States Diplomatic and Consular Staff in Tehran (United States v. Iran), Judgment, ICJ Reports (1980) p. 3, at para. 91, the ICJ determined that wrongful deprivation of human beings of their freedom and the subjection to physical constraint in conditions of hardship is in itself manifestly incompatible with the principles of the Charter of the United Nations. This indicates that the purposes and principles contain a broader content than the limited spectrum of jus cogens norms.

${ }^{54}$ Art. 53 of the Vienna Convention, supra n. 27, determines that: 'A treaty is void if, at the time of its conclusion, it conflicts with a peremptory norm of general international law. For the purposes of the present Convention, a peremptory norm of general international law is a norm accepted and recognized by the international community of states as a whole as a norm from which no derogation is permitted and which can be modified only by a subsequent norm of general international law having the same character.'

${ }^{55}$ The CFI assumes that this was the case in the Kadi decision, supra n. 1, at para. 226. 
tion in the affirmative, as anything else would allow states to circumvent their most fundamental obligations by creating an international organisation. ${ }^{56}$ However, one would have expected the European Court of First Instance to address this issue in a more elaborate manner. ${ }^{57}$

In essence the European Court of First Instance incorrectly limited the international value system applicable to the Security Council to the very narrow layer of peremptory norms. As a result, it significantly reduced the scope of the international value system that applies across regimes and increased the possibility for inter-regime normative conflict. For example, according to the European Court of First Instance's approach the Security Council resolution requiring the suspension of the right to a fair trial conflicted with the human rights obligations of the member states under the United Nations' human rights regime, the European human rights regime and the EU legal regime. Once such a conflict arises, the question becomes whether the Security Council obligations trump other obligations under international law in light of the supremacy clause in Article 103 of the Charter. The European Court of First Instance answered this question in the affirmative. $^{58}$

If one accepts that the Security Council itself is bound by the core content of the right to a fair trial, it is unlikely that the supremacy clause in Article 103 would be triggered in instances where the Security Council obliged member states to suspend this right. Article 25 of the Charter would arguably only apply to decisions that are intra vires. As a result, the primacy rule contained in Article 103 would not be applicable to decisions that were taken ultra vires and states would not be obliged to implement such decisions. ${ }^{59}$ However, such a determination should not be made lightly, given the Security Council's special role in the maintenance of international peace and security and the presumption of legality attached to its decisions. ${ }^{60}$ Instead, one should attempt to implement the Security Council resolution in manner that takes due account of the need to balance international

${ }^{56}$ See E. de Wet, 'The Prohibition of Torture as an International Norm of Jus Cogens and its Implications for National and Customary Law', 15 European Journal of International Law (2004) p. 97 at p. 97 et seq.; See also C. Tomuschat, 'Case Note on Ahmed Ali Yusuf and Al Barakaat International Foundation v. Council and Commission and Yassin Abdullah Kadi v. Council and Commission', 43 Common Market Law Review (2006) p. 537 at p. 546.

${ }^{57}$ In the Kadi decision, supra n. 1, at para. 231; See also Bulterman, supra n. 6, at p. 768-769.

${ }^{58}$ Kadi decision, supra n. 1, at paras. 183-184; Nada decision, supra n. 25, at para. 5; See also ICJ, Questions of the Interpretation and Application of the 1971 Montreal Convention arising from the Aerial Incident at Lockerbie (Libyan Arab Jamabiriya v. United Kingdom), Provisional Measures, Order of 14 April 1992, ICJ Reports (1992) p. 3, at para. 39; See also Tomuschat, supra n. 56, at p. 541.

59 See extensively De Wet \& Nollkaemper, supra n. 19, at p. 186-187; See also Thalinger, supra n. 42 , at p. 1027 et seq.

${ }^{60}$ ICJ, Certain Expenses of the United Nations, Advisory Opinion, ICJ Reports (1962) p. 151, at p. 168 et seq. 
peace and security with the applicable human rights norms at stake. ${ }^{61}$ This would, inter alia, imply that a limitation or derogation from human rights norms cannot be assumed unless provided for explicitly. ${ }^{62}$ In the case of Resolution 1267 (1999), ${ }^{63}$ this would mean that it necessarily (implicitly) allows states the necessary discretion to enforce the respective sanctions regime in accordance with human rights standards such as a right to a fair trial, even though this may not be self-evident from the resolution at first glance.

This solution is preferred to that of the European Court of Justice in the Kadi case, which granted comprehensive human rights protection exclusively on the basis of EU law. ${ }^{64}$ By not also addressing the European Court of First Instance's argument's pertaining to the Security Council's relationship with jus cogens norms, the purposes and principles of the Charter, as well as Article 103 of the Charter, it remains uncertain if and to what extent an inter-regime normative conflict did indeed exist in the present case. As a result, it remains uncertain whether European Union member states that provide extensive judicial protection to individuals when implementing Resolution 1267 (1999) ${ }^{65}$ and its follow-up resolutions would violate Security Council obligations and could face state responsibility claims on in the international level.

\section{ENFORCING THE INTERNATIONAL VALUE SYSTEM THROUGH REGIONAL AND DOMESTIC COURTS}

The practical value of this layered international value system is closely related to the question of its enforcement. In particular, the question arises whether the international community possesses structures capable of enforcing such a system and resolving potential normative conflicts between these norms and other international obligations. At the current stage of development of the international constitutional order, the international value system has to be enforced within a

${ }^{61}$ This argument can find support in the work of the report of the Study Group of the International Law Commission, 'Fragmentation of International Law: difficulties arising from the Diversification and Expansion of International Law', $58^{\text {th }}$ Session of the International Law Commission, A/CN.4/L.682, 13 April 2006, available via <http://www.un.org/law/ilc>, visited 18 Feb. 2009.

${ }^{62}$ See also J.E. Alvarez, 'The Security Council's War on Terrorism: Problems and Policy Options', in E. de Wet and A. Nollkaemper (eds.), Review of the Security Council by Member States (Antwerp, Intersentia 2003), p. 119 at p. 134.

${ }^{63}$ SC Res. 1267 (1999), supra n. 2.

${ }^{64}$ Kadi decision (ECJ), supra n. 10, at para 316 et seq.; See also A.G. Poiares Maduro, supra n. 10, at para. 59 et seq.; See also the well-known Solange decisions of the German Federal Constitutional Court, BVerfGE 37, 271 (1974) 29 May 1974 (Solange I); BVerfGE 73, 339 (1986), 22 Oct. 1986 (Solange II); see also BVerfGE 89, 155 (1993), 12 Oct. 1993 (Maastricht-Urtei); Judgments are available at <http://www.bundesverfassungsgericht.de>, visited 18 Feb. 2009.

${ }^{65}$ SC Res. 1267 (1999), supra n. 2. 
variety of institutional structures, given the absence of a binding, centralised international judiciary. ${ }^{66}$ It is therefore, inter alia, up to regional and functional judicial bodies, as well as domestic courts to enforce the emerging international value system in a decentralised fashion.

The question which arises is if, and to what extent, such judicial bodies are permitted under international law to interpret, apply and even review the legality of international norms generated by another international regime. After all, regional courts such as the European Court of First Instance and the European Court of Justice, functional judicial bodies such as World Trade Organisation dispute or International Centre for Settlement of Investment Disputes panels and domestic courts are principally set up to interpret and enforce the law of their own specific regime. However, this fact in itself would not prevent these bodies from also interpreting and enforcing norms generated by other international regimes - if, and to the extent to which, they are confronted with such norms. This view is supported by practice of the European courts during which they have claimed the competence of incidental review of decisions stemming from other international regimes for themselves.

In the European context such review has become common where the relationship between states' human rights obligations under the European Convention of Human Rights (ECHR) and other treaty obligations is concerned. The fact that neither the European Court of Human Rights nor the respective domestic courts were explicitly established with the purpose of engaging in the incidental review of different sets of international obligations has not prevented them from developing this competence in practice. ${ }^{67}$ The range of cases in which the European Court of Human Rights has reviewed the application of public international law obligations against the obligations in the ECHR range from absolute rights that may not be restricted or derogated from, even in times of war or public emergency, e.g., the prohibitions on torture and cruel, inhuman or degrading treatment and punishment; ${ }^{68}$ to rights that may be restricted for narrow purposes such as in times of emergency, e.g., the right to a fair trial; ${ }^{69}$ and rights that may be restricted

${ }^{66}$ De Wet 2006 (International Comparative Law Quarterly), supra n. 13, at p. 64 et seq.

${ }^{67}$ For relevant cases stemming from domestic courts see De Wet 2006 (Leiden Journal of International Law), supra n. 15, at p. 618 et seq.

${ }^{68}$ ECtHR 7 July 1989, Case No. 14038/88, Soering v. The United Kingdom; ECtHR 7 July 2004, Case No. 40653/98, Iorgov v. Bulgaria; ECtHR 4 Feb. 2005, Case Nos. 46827/99 and 46951/99, Mamatkulov \& Askarov v. Turkey; ECtHR 12 May 2005, Case No. 46221/99, Öcalan v. Turkey. All judgments are available at <http:/cmiskp.echr.coe.int>, visited 18 Feb. 2009; See also J. Dugard and C. Van den Wyngaert, 'Reconciling Extradition with Human Rights', 92 American Journal of International Law (1998), p. 187 at p. 210 et seq.

${ }^{69}$ ECtHR 18 Feb. 1999, Case No. 26083/94, Waite and Kennedy v. Germany; ECtHR 21 Nov. 2001, Case No. 35763/97, Al Adsani v. United Kingdom; ECtHR 21 Nov. 2001, Case No. 37112/97, 
for broad purposes, such as public safety, the protection of public order, the prevention of crime and the protection of the rights and freedoms of others, e.g., the right to privacy and family life; the right to vote, and the right to property. ${ }^{70}$

When reviewing other international obligations against the obligations in the ECHR, the European Court of Human Rights would first attempt to balance and reconcile the different international obligations at stake and would not easily conclude that there is a conflict between them. This is particularly the case where potential normative conflicts involving binding obligations of international organisations are concerned. For example, as far as the European Union is concerned, the European Court of Human Rights adopted a presumption of conformity of the actions of organs of the European Union with the obligations contained in the ECHR. ${ }^{71}$

Where Security Council resolutions are concerned, the European Court of Human Rights has thus far effectively avoided engaging in any incidental review. This was notably the case in the Behrami and Saramati decisions, where the European Court of Human Rights declared inadmissible a case that could have resulted in a potential conflict between obligations incurred under the ECHR and those resulting from Security Council resolutions. ${ }^{72}$ However, given the extraterritorial nature of these cases, it is uncertain whether they can serve as a precedent for disputes involving Security Council obligations on the one hand and ECHR obligations on the other hand and which concern events that occurred within the

Fogarty v. United Kingdom; ECtHR 21 Nov. 2001, Case No. 31253/96, McElbinney v. Ireland; ECtHR 20 June 2005, Case No. 45036/98, Bosphorus Hava Yollari Turzim ve Ticaret AS v. Minister of Transport, Energy and Communications, Ireland and the Attorney General (Bosphorus case). All judgments are available at <http:/cmiskp.echr.coe.int>, visited 18 Feb. 2009.

${ }^{70}$ ECtHR 18 Feb. 1999, Case No. 24833/94, Matthews v. United Kingdom; ECtHR, 9 July 2003, Case No. 48321/99, Slivenko v. Latvia; See also Bosphorus case, supra n. 69. All judgments are available at <http:/cmiskp.echr.coe.int>, visited 18 Feb. 2009.

${ }^{71}$ See Bosphorus case, supra n. 69.

72 ECtHR 31 May 2007, Case No. 71412/01, Agim Behrami and Bekir Behrami v. France and ECtHR 31 May 2007, Case No. 78166/01, Ru₹ hdi Saramativ. France, Norway and Germany. Both judgments are available at <http://cmiskp.echr.coe.int>, visited 18 Feb. 2009. The ECtHR concluded that the actions which were claimed to have violated Art. 2 and Art. 5(1) of the ECHR took place outside the territorial jurisdiction of any of its member states and in the absence of any effective control by a member state over these actions. Although member states such as France and Norway participated in the United Nations Kosovo Force (KFOR) in accordance with SC Res. 1244 of 10 June 1999, reprinted in $38 I L M 1999$ p. 1451, any alleged human rights violations that occurred in the course of their participation in KFOR had to be attributed to the United Nations. By coming to this rather convoluted conclusion, the ECtHR avoided a situation in which it had to review whether there was a conflict between the obligations of member states under the ECHR and obligations they have incurred in accordance with Security Council Resolution (1999); See extensively K.M. Larsen, 'Attribution of Conduct in Peace Operations: The "Ultimate Authority and Control" Test', 19 European Journal of International Law (2008), p. 509 at p. 509 et seq. 
territory of a member state. ${ }^{73}$ It therefore remains possible that the European Court of Human Rights may, when in future confronted with such a dispute, claim for itself the competence to exercise incidental review.

In contrast to the European Court of Human Rights, the European Court of Justice has - to some extent - engaged in review of Security Council resolutions on several occasions. This practice reveals that one can identify three types of incidental review. In the first scenario, the European Court of Justice had to interpret the scope of the European Union's implementation measures, and incidentally that of the relevant Security Council resolutions. However, in this situation neither the legality of the measures nor that of the Security Council resolutions were questioned. In the second scenario, the European Court of Justice was confronted with challenges to the legality of the implementing measures, but could avoid an incidental review of the legality of the respective Security Council measures. In this case the Security Council measures were formulated in broad terms, as a result of which those responsible for their implementation had discretion as to how to achieve the desired result. The third scenario concerned disputes about the legality of measures of implementation which incidentally also touched on the legality of the respective Security Council resolution. This was the case where the relevant Security Council resolutions were formulated in narrow terms which did not prima facie allow the member states (or the European Union) any discretion in relation to their implementation. As far as the first two scenarios are concerned, the European Court of Justice has not hesitated to exercise its competence in the past, even though such review was not provided for under the Charter. This suggests that international law has developed in a manner that permits domestic and regional courts some discretion in interpreting or even reviewing Security Council resolutions.

The first example (pertaining to the first scenario mentioned above) concerns the Bosphorus decision. ${ }^{74}$ In that instance, the European Court of Justice had to determine the scope of European Community Regulation 1990/1993 $3^{75}$ and, in particular, whether it authorised the impoundment by the Irish authorities of two aircrafts leased to the applicant by the former Yugoslav airline Jugoslovenski Aero Transport (JAT). As the respective European Community Regulation implemented a Security Council sanctions regime against the former Federal Republic of Yugoslavia, the European Court of Justice also had to determine the scope of Security

\footnotetext{
${ }^{73}$ See Kadi decision (ECJ), supra n. 10, at para 312 et seq.; See also A.G. Poiares Maduro, supra n. 10 , at footnote 42 .

${ }^{74}$ Bosphorus case, supra n. 69; See also ECJ 11 Oct. 2007, Case C-117/06, Gerda Möllendorf and Christina Möllendorf-Niebuus (Möllendorf case).

${ }^{75}$ Council Regulation 1990/93, OJ [1993] L 102/14, 28.4.1993.
} 
Council Resolution 820 of 17 April 1993. ${ }^{76}$ The European Court of Justice also took the purpose of the sanctions regime into account when concluding that the limitation of the applicant's right to property under international law (he effectively lost three years of a four year lease) was proportionate under the circumstances. ${ }^{77}$ However, neither the legality of European Community Regulation 1990/ $1993^{78}$ nor the sanctions regime from which it resulted was in question.

The second example (concerning the second scenario), is that of the Segi case. ${ }^{79}$ In this instance the European Court of Justice reviewed the European Union measures implementing Security Council Resolution 1373 of 28 September 2001, ${ }^{80}$ which, inter alia, requested United Nations member states to freeze all funds and other financial assets or economic resources to those involved in terrorist activity. ${ }^{81}$ In order to ensure consistent implementation of this resolution in its member states, the European Union implemented this resolution through a series of measures that, inter alia, resulted in the blacklisting of the Basque organisation Segi. ${ }^{82}$ The applicants filed an action for damages as a result of the relevant European Union measures, on the basis that those measures violated their international right to judicial protection in accordance with Article 6(2) of the Treaty on European Union (EU Treaty). ${ }^{83}$ In accordance with their line of argument, the violation resulted from the fact that they had no means of challenging Segi's inclusion in the blacklist, due to the nature of the Common Positions that were adopted under the so-called third pillar of the EU Treaty. Effectively, this claim also constituted an indirect challenge to the validity of the relevant Common Position. ${ }^{84}$

${ }^{76}$ SC Res. 820 of 17 April 1993, available via <http://www.un.org/Docs/scres/1993/scres93. htm>, visited 18 Feb. 2009; See also Bosphorus decision, supra n. 69, at para. 15.

77 Bosphorus decision, supra n. 69, at para. 26; See also Bulterman, supra n. 6, at p. 767.

${ }^{78}$ Council Regulation 1990/93, supra n. 75.

${ }^{79}$ ECJ 27 Feb. 2007, Case C-355/04, Segi and others v. Council of the European Union (Segi case) available via <http://curia.europa.eu>, visited 18 Feb. 2009.

${ }^{80}$ SC Res. 1373 of 28 Sept. 2001, reprinted in 40 ILM 2001, p. 1278.

${ }^{81}$ See also Bulterman, supra n. 6, at p. 757.

82 See, inter alia, Council Common Position 2001/931/CFSP on the application of specific measures to combat terrorism, OJ [2001] L 344/90, 28.12.2001; Council Regulation 2580/2001 on specific restrictive measures directed against certain persons and entities with a view to combating terrorism, OJ [2001] L 344/70, 28.12.2001; Council Decision 2001/927/EC establishing the list provided for in Art. 2(3) of Council Regulation 2580/2001 on specific restrictive measures directed against certain persons and entities with a view to combating terrorism, OJ [2001] L 344/83, 28.12.2001; Council Common Position 2002/340/CFSP updating Common Position 2001/931/ CFSP on the application of specific measures to combat terrorism, OJ [2002] L 116/75, 3.5.2002; Council Common Position 2002/462/CFSP updating Common Position 2001/931/CFSP on the application of specific measures to combat terrorism and repealing Common Position 2002/340/ CFSP, OJ [2002] L 160/32, 18.6.2002.

${ }^{83}$ Treaty on European Union (7 Feb. 1992), OJ [1992] C 191/1, 29.7.1992.

${ }^{84}$ See Segi decision, supra n. 79, at para. 52 et seq. 
In reviewing the matter and concluding that EU law indeed provided for an avenue of legal protection in this case, the European Court of Justice emphasised the applicants' right to a remedy and access to a court of law. ${ }^{85}$ However, it is important to note that Security Council Resolution $1373(2001)^{86}$ clearly left states the discretion to implement the obligations contained therein in accordance with international human rights obligations. For example, it did not identify the persons to be blacklisted in a manner that appeared to suspend any avenue of (domestic) legal protection for such individuals. ${ }^{87}$ As a result, the question of whether the respective implementing measures were in accordance with the European Union standards of legal protection could be addressed without raising the issue of the possible illegality of Security Council Resolution $1373(2001)^{88}$ itself.

The Kadi case ${ }^{89}$ represents the third scenario mentioned above. In these instances the European Court of First Instance and subsequently the European Court of Justice was confronted with a request for an annulment of European Community regulations. However, due to the manner in which these regulations implemented a Security Council sanctions regime, the request for annulment unavoidably also touched on the issue of the legality of the Security Council measures. As these regulations were near-literal transpositions of the relevant Security Council resolutions, any review of the substance of the challenged regulations necessarily amounts to indirect review of the relevant Security Council measures. ${ }^{90}$ The European Court of First Instance concluded that it did not have any general competence to exercise such incidental review, the only exception being where jus cogens norms were affected. ${ }^{91}$ At this point it is necessary to mention that the European Court of Justice drew a similar conclusion. Although its decision turned on EU law, the European Court of Justice did note that it did not have the jurisdiction to review incidentally the lawfulness of a decision adopted by an international body. Moreover, the ECJ was not willing to accept that any exception existed in relation to the compatibility of the international decisions with peremptory norms of international law. ${ }^{92}$

${ }^{85}$ Council Common Position 2001/931/CFSP, supra n. 82; See also Segi decision, supra n. 79, at paras. 51-52, 54.

${ }^{86}$ SC Res. 1373 (2001), supra n. 80.

${ }^{87}$ See in particular ECJ, Opinion of A.G. Mengozzi, 26 Oct. 2006, Case C-355/04 P, Segi and others v. Council of the European Union at para. 57, available at <http://curia.europa.eu $>$ under Case C-354/04 P, visited 18 Feb. 2009; See also Bulterman, supra n. 6, at p. 757.

${ }^{88}$ SC Res. 1373 (2001), supra n. 80.

${ }^{89}$ Kadi case, supra n. 1.

${ }^{90}$ Tomuschat, supra n. 56 at p. 543.

${ }^{91}$ Kadi decision, supra n. 1, at paras. 221, 225-226; See also Nada decision, supra n. 25 at para. 6.2.

${ }^{92}$ Kadi decision (ECJ), supra n. 10, para. 287. 
Both courts drew their conclusion in a categorical fashion that was devoid of substantive reasoning. One would have expected them to provide more extensive motivation as to why they would have the power to both review the scope of Security Council decisions and balance these obligations against other international (human rights) obligations of states, but not the power to review the legality of such decisions. In addition, the European Court of First Instance and the European Court of Justice could have considered the potential relevance of previous, wellknown international decisions that confirmed the power of the respective international courts or tribunals to review the legality of Security Council resolutions. The first such case concerns the Namibia opinion of the International Court of Justice, ${ }^{93}$ in which the latter Court confirmed the power of the General Assembly and the Security Council to terminate a League of Nations mandate. In doing so, the International Court of Justice effectively reviewed the legality of binding Security Council resolutions terminating South Africa's mandate over (the then) South-West Africa. Whilst acknowledging that it was not a court of appeal, the International Court of Justice nonetheless - in the exercise of its judicial function - considered the validity of the respective Security Council resolutions and concluded that they were adopted in accordance with the Charter. ${ }^{94}$

Similarly, in the Tadic decision, ${ }^{95}$ the Appeals Chamber of the International Criminal Tribunal for the former Yugoslavia, itself a sub-organ of the Security Council, reviewed the legality of the Chapter VII resolution by means of which the Security Council created the International Criminal Tribunal for the former Yugoslavia. Relying, inter alia, on the Namibia opinion of the International Court of Justice, ${ }^{96}$ the Appeals Chamber concluded that it had the inherent jurisdiction to determine its own jurisdiction, which effectively amounted to the competence to review the legality of the relevant Security Council resolution 'in the exercise of its judicial function'. Of course one has to acknowledge that the European Court of First Instance and European Court of Justice are not in any way bound by these decisions. What is more, the nature of the International Court of Justice and the International Criminal Tribunal for the former Yugoslavia is very different from that of European Court of First Instance and the European Court of Justice. Whereas the two former courts are international institutions, the latter

${ }^{93}$ ICJ, Legal Consequence for States of the Continued Presence of South Africa in Namibia (South West Africa) Notwithstanding Security Council Resolution 276 (1970) (Namibia case), Advisory Opinion, ICJ Reports (1971) p. 16.

${ }^{94}$ See also Tomuschat, supra n. 56, at p. 545.

${ }^{95}$ ICTY Appeals Chamber, Decision on the Defence Motion for Interlocutory Appeal and Jurisdiction, 2 Oct. 1995, Case IT-94-1-AR72, Prosecutor v. Dusko Tadic a/k/a "Dule" (Tadic case), at para. 27 et seq. The decision is available at <www.un.org/icty/>, visited 18 Feb. 2009.

${ }^{96}$ Namibia case, supra n. 93. 
two, given their centralised nature, arguably bear more resemblance to municipal courts. $^{97}$

Even so, one should keep in mind that all of these institutions are independent judicial bodies, none of whose statutes explicitly provide for the competence to review the legality of Security Council resolutions. (However, the International Court of Justice and the International Criminal Tribunal for the former Yugoslavia did not let this fact prevent them from claiming an implicit right to review Security Council resolutions.) In addition, they all share two common functions, namely the settlement of disputes in accordance with law and the administration of justice. ${ }^{98}$ A coherent and systemic approach to international law across different regimes would have required the European Court of First Instance and the European Court of Justice to explain whether these facts have any bearing on its own competence to review Security Council resolutions and if so (or if not), why (not). Moreover, if one accepted that no power of review existed, one would also have expected an explanation by the European Court of First Instance as to why an exception would exist in relation to jus cogens norms. In this respect the position of the European Court of Justice was more consistent, as it did not accept the existence of such an exception.

It is fair to assume that the reluctance of the European Court of First Instance to acknowledge a (broad) competence of review 'in the exercise of its judicial function' of Security Council resolutions, relates to the potential undermining effect that this could have on Charter obligations. ${ }^{99}$ For example, it could open the door for states to avoid their Charter obligations by forwarding pre-textual arguments of illegality. At the same time, one should balance this risk against the fact that, in the absence of judicial control by member states, the powers of the Security Council are at risk of becoming absolute. This, in turn, would threaten the legitimacy and the functioning of the United Nations system itself, if it were to result in the upholding of Security Council decisions which undermined the very norms upon which the United Nations was based. ${ }^{100}$ For this reason, the author would argue in favour of domestic and regional review, keeping in mind that these courts will attribute significant weight to the presumption of legality

${ }^{97}$ In addition, the Tadic decision, supra n. 95, was tainted by the fact that the ICTY had to review the legality of its own creation, which effectively made it a judge in its own case, see De Wet 2004 (The Chapter VII Powers of the United Nations Security Council), supra n. 49, at p. 65-66.

98 See also C. Brown, A Common Law of International Adjudication (Oxford, Oxford University Press 2007), at p. 230 et seq., where this argument is developed in relation to international courts and tribunals and the administration of international justice.

${ }^{99}$ See also the Nada decision, supra n. 25, at para. 6.2; See also A.G. Poiares Maduro, supra n. 10, at para. 38 .

${ }^{100}$ See also Orakhelashvili, supra n. 28, at p. 192. 
attached to Security Council resolutions and the importance of that organ's role as the primary guardian of international peace and security. ${ }^{101}$

As far as the European Court of Justice is concerned, the motivations for its conclusion are less clear, given that it did provide for judicial review on the basis of EU law. Even though this approach did not lead to any decision on the legality of the Security Council resolutions as such, it is unlikely that it was motivated by a fear of undermining the Charter system. After all, the annulment of the Community acts that implement binding Security Council resolutions can be equally disruptive - if the efficacy of the Charter system is one's major concern. Such an annulment could effectively result in a non-implementation or mere partial implementation of Charter obligations. It is more likely that that approach of the European Court of Justice to focus exclusively on fundamental values with the EU legal order was motivated by a desire to avoid an open conflict with the Security Council and its permanent members, two of whom are also members of the EU.

\section{Conclusion}

In light of the above analysis, one can conclude that the European Court of First Instance Kadi case ${ }^{102}$ has, in principle, confirmed the existence of a hierarchy in international law that would also constitute an outer limit for Security Council action. It has also confirmed a (limited) role for domestic and regional courts in enforcing this hierarchy. This could be regarded as confirmation of a nascent international constitutional order along the lines outlined above in section 1. Closer scrutiny nonetheless reveals that this development does not yet result in any meaningful human rights protection when human rights infringements are likely to result from binding Security Council resolutions.

This relates to the European Court of First Instance's flawed interpretation of the third layer of the international value system identified above, namely the scope of the international human rights obligations applicable to the United Nations and its organs. In doing so, the European Court of First Instance effectively devaluated the standing of this emerging order and increased the possibility of inter-regime conflict whenever both Security Council resolutions and human rights norms are applicable. Under these circumstances, meaningful human rights protection would only be possible by applying the more human rights-friendly regime - whether of a regional or domestic constitutional nature - at the expense of, for example, an international regime directed at the protection of international peace and security.

${ }^{101}$ De Wet and Nollkaemper, supra n. 19, at p. 196 et seq.

${ }^{102}$ Kadi case, supra n. 1. 
This is also the upshot of the approach that was followed by the European Court of Justice during the appeal of the Kadi case, ${ }^{103}$ even though it did not address the European Court of First Instance's reasoning pertaining to the human rights obligations binding on the Security Council. By exclusively focusing on (certain aspects of) the European Union value system in coming to its decision to grant extensive judicial protection, the European Court of Justice enhanced the perception that there indeed may have existed an inter-regime normative conflict, which could only be resolved by protecting either one of the regimes. Similarly, neither the European Court of First Instance nor the European Court of Justice gave sufficient recognition to the increasing role of regional and domestic courts in enforcing the international value system. Although these courts first and foremost serve to enforce the law of their own legal order, they also have a secondary role in enforcing the emerging international constitutional order. ${ }^{104}$

On the positive side, one has to acknowledge, of course, that if strong and influential courts like the European Court of Justice were to provide extensive human rights protection in a consistent matter, this may, in time, have a 'bottomup spillover' effect on United Nations organs and other international actors. They would be forced to give better recognition to international human rights standards as a matter of practical reality, as anything else may lead to the non-observance of their decisions. However, on a practical level such an approach leaves unresolved - in the short- and medium-term - the question of whether and to what extent the United Nations and its organs are bound by international human rights standards (in the sense of a third layer of an international value system) and whether states that do not implement Security Council resolutions that infringe international human rights standards, would actually be in violation of a Security Council resolution. On a conceptual level, it also leaves open the question whether international law has developed in a manner which provides safeguards against the (re-) establishment of absolute public power by international organisations over private individuals.

The better approach for regional and domestic courts would therefore be to acknowledge the more extensive human rights obligations of the United Nations regime and their resemblance to other regional or domestic obligations for human rights protection. On a practical level, this would imply that regional and domestic courts interpret Security Council resolutions in accordance with the Security Council's own human rights obligations. In the process, they would hold govern-

103 See Kadi decision (ECJ), supra n. 10, para. 316, 326; See also A.G. Poiares Maduro, supra n. 10.

${ }^{104}$ Cf. Brown, supra n. 98, at p. 55, who suggests that the emergence of common standards in the procedure and remedies applied in international adjudication can serve as an indication that international courts are beginning to operate as if they formed part of the same system - despite lacking any formal connections between them. 
ments to their obligation to implement Security Council obligations whether pertaining to sanctions or otherwise, whilst simultaneously giving effect to the core content of their own international human rights obligations (as well as those of the United Nations). In this manner a zero-sum scenario is avoided where international human rights obligations are implemented at the expense of international peace and security, or vice versa. In conceptual terms, such an approach would also contribute to developing a system where the supreme (legal) framework for (the control over) exercise of public power can be found in the interaction between national, regional and functional regimes and the core value system common to all regimes. 